University of Nebraska - Lincoln

DigitalCommons@University of Nebraska - Lincoln

Comparison of aerodynamic and radiometric surface temperature using precision weighing lysimeters

\author{
Paul D. Colaizzi \\ USDA-ARS, Paul.Colaizzi@ARS.USDA.GOV \\ Steven R. Evett \\ USDA-ARS, steve.evett@ars.usda.gov \\ Terry A. Howell \\ USDA-ARS, Terry.Howell@ars.usda.gov \\ Judy A. Tolk \\ USDA-ARS
}

Follow this and additional works at: https://digitalcommons.unl.edu/usdaarsfacpub

Colaizzi, Paul D.; Evett, Steven R.; Howell, Terry A.; and Tolk, Judy A., "Comparison of aerodynamic and radiometric surface temperature using precision weighing lysimeters" (2004). Publications from USDAARS / UNL Faculty. 1819.

https://digitalcommons.unl.edu/usdaarsfacpub/1819

This Article is brought to you for free and open access by the U.S. Department of Agriculture: Agricultural Research Service, Lincoln, Nebraska at DigitalCommons@University of Nebraska - Lincoln. It has been accepted for inclusion in Publications from USDA-ARS / UNL Faculty by an authorized administrator of DigitalCommons@University of Nebraska - Lincoln. 


\title{
Comparison of aerodynamic and radiometric surface temperature using precision weighing lysimeters
}

\author{
Paul D. Colaizzi ${ }^{* a}$, Steven R. Evett ${ }^{\mathrm{a}}$, Terry A. Howella, Judy A. Tolk ${ }^{\mathrm{a}}$ \\ ${ }^{a}$ USDA-Agricultural Research Service, P.O. Drawer 10, Bushland, TX 79012-0010 \\ *pcolaizzi@cprl.ars.usda.gov; phone 1806356 5763; fax 1806356 5750; http://www.cprl.ars.usda.gov
}

\begin{abstract}
Radiometric surface temperature $\left(\mathrm{T}_{\mathrm{s}}\right)$ is commonly used as a surrogate for aerodynamic temperature $\left(\mathrm{T}_{\mathrm{o}}\right)$ in computing the sensible heat flux term $(\mathrm{H})$ in the energy balance. However, these temperatures may differ by several degrees, leading to possible errors (especially for large H) and their relationship is not well known. Previous researchers have established empirical and semi-empirical parameterizations of the radiometric roughness length $\left(\mathrm{z}_{\mathrm{or}}\right)$ or some related form (e.g., $\mathrm{kB}_{\mathrm{r}}^{-1}=\ln \left[\mathrm{z}_{\mathrm{om}} / \mathrm{z}_{\mathrm{or}}\right]$, where $\mathrm{z}_{\mathrm{om}}$ is the momentum roughness length). In this paper, we estimated $T_{o}-T_{a}$ (where $T_{a}$ is air temperature at $2 \mathrm{~m}$ height) and $\mathrm{z}_{\mathrm{or}}$ using large, precision weighing lysimeters planted with irrigated alfalfa, irrigated and dryland cotton, and dryland grain sorghum. $\mathrm{T}_{\mathrm{s}}$ was measured by infrared thermometers mounted over the lysimeters. No apparent relations were found between $\left(T_{o}-T_{a}\right)$ and $\left(T_{s}-T_{a}\right)$ or between $\mathrm{z}_{\mathrm{or}}$ (in the $\mathrm{kB}_{\mathrm{r}}^{-1}$ form) and meteorological variables or leaf area index (LAI). The $\mathrm{kB}_{\mathrm{r}}^{-1}$ parameter appeared to be most influenced by the different surface roughness of each crop type. Using constant $\mathrm{kB}_{\mathrm{r}}^{-1}$ values established for each type of surface, the energy balance model showed reasonable agreement with $\mathrm{H}$ and LE derived from lysimeter measurements.
\end{abstract}

Keywords: aerodynamic temperature, radiometric temperature, lysimeters, energy balance, evapotranspiration

\section{INTRODUCTION}

There is considerable interest in using remotely sensed surface temperature to estimate evapotranspiration (ET), particularly for cropped surfaces, through the energy balance equation. Perhaps the most serious assumption of this method concerns the sensible heat flux term $(\mathrm{H})$, specifically in using radiometric surface temperature as a surrogate for aerodynamic surface temperature. When $\mathrm{H}$ is small relative to other components, such as for actively transpiring cropped surfaces where soil background is absent and advective heat input is small, this does not appear to be a significant issue, and good agreement has been reported between measured ET and surface temperature - energy balance models (Hatfield et al., 1984; Reginato et al., 1985; Huband and Monteith, 1986b; Choudhury et al., 1986; Jackson et al., 1987; Moran et al., 1989). Agreement between measured and modeled ET declined, however, when H became a larger component of the energy balance, such as for partial crop cover (Hatfield et al., 1984; Jackson et al., 1987) and dry or water stressed vegetation (Kustas et al., 1989; Kalma and Jupp, 1990), implying that radiometric temperature is not always a good representation for aerodynamic temperature for these surfaces.

A number of studies reported various levels of differences between radiometric and aerodynamic surface temperature (e.g., Huband and Monteith, 1986a; Choudhury et al., 1986; Alves et al., 2000a; 2000b). The definition of aerodynamic temperature itself depends on assumptions about the heat/vapor transport roughness length $\left(\mathrm{z}_{\mathrm{oh}}\right)$, which cannot be measured directly, and is therefore usually assumed to be 0.1 to 0.2 of momentum roughness length $\left(\mathrm{z}_{\mathrm{om}}\right)$, since sensible heat transfer by diffusion is governed by momentum exchange. Momentum roughness length is usually assumed to be proportional to canopy height. Additional assumptions include the shape of the wind and temperature gradient curves, which can be influenced by stability, turbulence, and choice of stability functions, among other parameters (Sun et al., 1999; Mahrt and Vickers, 2004).

Choudhury et al. (1986) compared radiometric and aerodynamic temperatures (derived from lysimeters) for a full cover, non-water-stressed wheat canopy in Phoenix, Arizona. They found they were nearly equal for neutral conditions, but radiometric temperature was greater (less) than aerodynamic temperature for stable (unstable)

Published in:

Remote Sensing and Modeling of Ecosystems for Sustainability

edited by Wei Gao, David R. Shaw, Proceedings of SPIE Vol. 5544

(SPIE, Bellingham, WA, 2004) . 0277-786X/04/\$15 . doi: 10.1117/12.559503 
conditions. Considering vertical temperature gradients for lapse (unstable) and stable conditions, this implied that the radiometer was effectively viewing the top of the canopy (height $h_{c}$ ), and the location of the virtual source-sink for sensible heat was within the canopy (i.e., at the height of scalar roughness length above the zero plane displacement height $d$, or $d+z_{o h}$ ). Despite some differences between temperatures for non-neutral conditions, they showed that inclusion of $\mathrm{H}$ using radiometric temperature improved $\mathrm{ET}$ estimates over those when $\mathrm{H}$ was neglected.

Alves et al. (2000a) reported radiometric temperatures up to $7^{\circ} \mathrm{C}$ less than aerodynamic temperatures (derived from Bowen ratio measurements in neutral conditions) for full-cover, well-watered winter wheat and iceberg lettuce in the Mediterranean climate of Portugal. They attributed their differing results to possible inaccuracies of lysimeters used in other studies, additive errors in residual methods of estimating sensible heat flux, differences in water stressed conditions, atmospheric buoyancy/stability, and especially to the greater aridity of their location in Portugal (although many of the other studies were conducted around Phoenix, Arizona). However, their crops were drip-irrigated almost daily to the extent that they observed condensation both inside the plant canopies and on the soil surface during daytime hours, indicating saturated air inside the canopy. This would drive the source-sink for sensible and latent heat flux toward the top of the canopy and into view of the radiometer. Alves et al. (2000b), following the suggestion of Wanjura and Upchurch (1996), then showed that under these conditions, radiometric surface temperature could be interpreted as the wet bulb of the surface aerodynamic temperature.

Numerous strategies have been proposed that involve either relating radiometric temperature to aerodynamic temperature, or establishing some radiometric roughness length (denoted $\mathrm{z}_{\mathrm{or}}$ in this paper) used in the bulk aerodynamic resistance equation that would give the correct $\mathrm{H}$ using radiometric temperature, or a combination of both. Chehbouni et al. (1996) found that the ratio of the aerodynamic- and radiometric-air vertical temperature gradients $\left[\left(T_{0}-T_{a}\right) /\left(T_{s}-T_{a}\right)\right]$ were constant throughout a given day but changed according to leaf area index (LAI) for arid grassland in the Sahel region of West Africa. They were able to correlate a reflectance vegetation index to LAI and parameterize LAI to $\mathrm{T}_{0}-$ $\mathrm{T}_{\mathrm{a}}$. They found good agreement with sensible heat flux obtained by coupled multi-source vegetation-hydrologic models and Bowen ratio measurements. Mahrt and Vickers (2004) related aerodynamic and radiometric temperature through a simple parameterization of LAI and incoming solar radiation for bare soil, grass, crops, and forests. When vegetation does not fully cover the soil, more complex approaches to estimate $T_{0}-T_{a}$ from $T_{s}$ are required, such as dual-source models (Crago, 1998; Lhomme et al., 1994), or multi-angle measurements (Chehbouni et al., 2001; Merlin and Chebouni, 2004; Zibognon et al., 2002).

The scalar roughness length $\left(\mathrm{z}_{\mathrm{oh}}\right)$ can be regarded as an additional resistance to momentum transfer (and is therefore less than $\mathrm{z}_{\mathrm{om}}$ ) and is often expressed as (Chamberlain, 1968):

$$
\mathrm{kB}^{-1}=\ln \left[\frac{\mathrm{z}_{\mathrm{om}}}{\mathrm{z}_{\mathrm{oh}}}\right] .
$$

The $\mathrm{kB}^{-1}$ parameter has been described by simple empirical models and has usually been verified by Bowen ratio or eddy correlation measurements. Kustas et al. $(1989 ; 1994)$ related $\mathrm{kB}^{-1}$ to the product of wind speed and radiometric-air temperature difference $\left[u\left(T_{s}-T_{a}\right)\right]$ over desert brush and semiarid grassland. Similarly, Zhang et al. (1995) used the product of friction velocity $\left(\mathrm{u}_{*}\right)$ and radiometric-air temperature difference $\left[\mathrm{u}_{*}\left(\mathrm{~T}_{\mathrm{s}}-\mathrm{T}_{\mathrm{a}}\right)\right]$ over forest and crops. Qualls and Brutsaert (1996) showed that the spatial distribution of $\mathrm{z}_{\mathrm{oh}}$ used in Monin-Obukov similarity theory depended largely on LAI for prairie grass and, on a theoretical basis, $u_{*}$ temporally. It is possible the dependence of $z_{o h}$ on $T_{s}-T_{a}$ observed by others may actually be in part due to its dependence on LAI. Lhomme et al. (2000) described a parameterization of $\mathrm{B}^{-1}$ in terms of sensor view angle and LAI, and this was used by Suleiman and Crago (2004) to estimate ET of grassland through a dimensionless temperature parameter (instead of the residual energy balance).

The objective of this paper is to test the energy balance equation using ground-based radiometric surface temperatures recorded over large, precision weighing lysimeters for several years of irrigated and dryland full cover crops in the Southern High Plains region of Texas. We will assess what differences, if any, exist between radiometric and aerodynamic surface temperatures, and determine if such differences can be alleviated by a simple $\mathrm{kB}^{-1}$ parameterization under the wide range of climatic conditions found at this location. 


\section{ENERGY BALANCE EQUATIONS}

The energy balance equation considers one-dimensional energy flux at the soil-plant-atmosphere continuum and is given as:

$$
L E=R_{n}-G-H
$$

where LE is the latent heat flux, $\mathrm{Rn}$ is the net radiation at the surface, $\mathrm{G}$ is the soil heat flux, and $\mathrm{H}$ is the sensible heat flux, all in units of $\left(\mathrm{W} \mathrm{m}^{-2}\right)$. The available energy $\left(R_{n}-G\right)$ may be measured directly, or estimated by meteorological measurements (Allen et al., 1998), where $R_{n}$ is mainly a function of incoming solar radiation and humidity and $G$ is a fraction of $\mathrm{R}_{\mathrm{n}}$, or also include reflected and emitted radiation that is spatially-distributed (Jackson et al., 1985).

Sensible heat flux $\mathrm{H}$ is given by a temperature gradient-resistance equation,

$$
H=-\frac{\rho C_{p}}{r_{a}}\left(T_{o}-T_{a}\right)
$$

where $\rho$ is the density of air $\left(\mathrm{kg} \mathrm{m}^{-3}\right), \mathrm{C}_{\mathrm{p}}$ is the specific heat of air $\left(=1013 \mathrm{~kJ} \mathrm{~kg}^{-1}{ }^{\circ} \mathrm{C}^{-1}\right), \mathrm{T}_{\mathrm{o}}$ and $\mathrm{T}_{\mathrm{a}}$ are the aerodynamic surface and air temperatures, respectively $\left({ }^{\circ} \mathrm{C}\right)$, and $r_{a}$ is the bulk aerodynamic resistance for heat and momentum $\operatorname{transfer}\left(\mathrm{s} \mathrm{m}^{-1}\right)$.

The bulk aerodynamic resistance is

$$
\mathrm{r}_{\mathrm{a}}=\frac{\ln \left[\frac{\mathrm{z}-\mathrm{d}}{\mathrm{z}} \mathrm{oh}\right]-\Psi_{\mathrm{h}}}{\mathrm{ku}_{*}}
$$

where $\mathrm{z}$ is the reference height above the canopy (in the fully adjusted boundary layer) where temperature and wind speed are measured $(\mathrm{m}), \mathrm{d}$ is the zero plane displacement $(\mathrm{m}), \mathrm{z}_{\mathrm{oh}}$ is the scalar roughness length for sensible heat transfer $(\mathrm{m}), \Psi_{\mathrm{h}}$ is a stability correction function for heat transfer (dimensionless), $\mathrm{k}$ is the von Karman $(=0.41)$, and $\mathrm{u}_{*}$ is the friction velocity, given by

$$
\mathrm{u}_{*}=\frac{\mathrm{ku}}{\ln \left[\frac{\mathrm{z}-\mathrm{d}}{\mathrm{z}_{\mathrm{om}}}\right]-\Psi_{\mathrm{m}}}
$$

where $\mathrm{u}$ is the wind speed $\left(\mathrm{m} \mathrm{s}^{-1}\right), \mathrm{z}_{\mathrm{om}}$ is the roughness height for momentum $(\mathrm{m}), \Psi_{\mathrm{m}}$ is the stability correction function for momentum (dimensionless), and all other terms are as defined previously.

The $\mathrm{d}$ and $\mathrm{z}_{\mathrm{om}}$ terms are commonly taken as a fraction of the canopy height for full cover, uniform crops [e.g., 0.67 and 0.123, respectively (Allen et al., 1989; Tolk et al. 1995)]. Perrier (1982) and Pereira et al. (1999) give expressions that account for leaf area index, which we found gave better results than constant values:

$$
\begin{aligned}
& \mathrm{d}=\mathrm{h}_{\mathrm{c}}\left[1-\frac{2}{\mathrm{LAI}}\left(1-\mathrm{e}^{-\mathrm{LAI} / 2}\right)\right] \\
& \mathrm{z}_{\mathrm{om}}=\mathrm{h}_{\mathrm{c}} \mathrm{e}^{-\mathrm{LAI} / 2\left(1-\mathrm{e}^{-\mathrm{LAI} / 2}\right)}
\end{aligned}
$$


where $h_{c}$ is the canopy height $(\mathrm{m})$ and LAI is leaf area index (one side of leaf area per ground area), and equations (6) and (7) are valid for $\mathrm{LAI} \geq 0.5$. The $\mathrm{z}_{\mathrm{oh}}$ term is commonly assumed to be a constant fraction of $\mathrm{z}_{\mathrm{om}}$ because the former is governed by the latter:

$$
\mathrm{z}_{\mathrm{oh}}=\mathrm{az}_{\mathrm{om}} \cdot
$$

For full cover crops, $\mathrm{a}=0.1$ and for tall or partial cover crops, a = 0.2 (Monteith, 1973; Campbell, 1977; Brutsaert, 1982; Allen et al., 1989; Jensen et al., 1990). These expressions assume that the vegetation can be reduced to a "big leaf," which is extensive, level, at height $\mathrm{d}+\mathrm{z}_{\mathrm{oh}}$, where all exchanges of sensible at latent heat (vapor) occur (Monteith, 1973). In the case of full cover, non-water stressed vegetation, or low atmospheric demand, the area toward the top of the canopy (between $d+z_{o h}$ and $h_{c}$ ) can also contribute significantly to vapor flux, as demonstrated by Alves et al. (2000a), hence an alternative is to replace $z_{o h}$ with $h_{c}-d$ in equation (4) (Perrier, 1975). This places the big leaf at the top of the canopy.

The stability correction functions $\left(\Psi_{\mathrm{h}}\right.$ and $\left.\Psi_{\mathrm{m}}\right)$ are based on Monin-Obukhov similarity theory (Monin and Obukhov, 1954). For neutral conditions, $\Psi_{\mathrm{h}}=\Psi_{\mathrm{m}}=0$. For stable conditions, expressions for $\Psi_{\mathrm{h}}$ and $\Psi_{\mathrm{m}}$ are (Webb, 1970):

$$
\Psi_{\mathrm{h}}=\Psi_{\mathrm{m}}=-5 \frac{\mathrm{z}-\mathrm{d}}{\mathrm{L}}
$$

where $\mathrm{L}$ is the Monin-Obukhov length, expressed as:

$$
L=\frac{\rho C_{p} u_{*}^{3}\left(T_{o}+273.16\right)}{g k H}
$$

where $\mathrm{g}$ is the acceleration of gravity $\left(=9.81 \mathrm{~m} \mathrm{~s}^{-2}\right)$ and all other terms are as defined previously. Note that $\mathrm{T}_{\mathrm{o}}$ is converted to Kelvin $(\mathrm{K})$ temperature by the addition of 273.16. Equation (10) is in the form where $\mathrm{H}$ is positive toward the canopy, and $\mathrm{L}>0$ for stable and $\mathrm{L}<0$ for unstable conditions. For unstable conditions, expressions for $\Psi_{\mathrm{h}}$ and $\Psi_{\mathrm{m}}$ are (Paulson, 1970):

$$
\begin{array}{r}
\Psi_{\mathrm{h}}=2 \ln \left[\frac{1+\mathrm{X}^{2}}{2}\right] \\
\Psi_{\mathrm{m}}=2 \ln \left[\frac{1+\mathrm{X}}{2}\right]+\ln \left[\frac{1+\mathrm{X}^{2}}{2}\right]-2 \arctan (\mathrm{X})+\frac{\pi}{2}
\end{array}
$$

where

$$
X=\left[1-16 \frac{(z-d)}{L}\right]^{0.25}
$$




\section{PROCEDURE}

\subsection{Location and lysimeters}

Crop water use was measured by four large precision weighing lysimeters at Bushland, Texas $\left(35^{\circ} 11^{\prime} \mathrm{N}\right.$ lat., $102^{\circ} 06^{\prime} \mathrm{W}$ long., 1,170 m elevation M.S.L.). The climate is semi-arid with a high evaporative demand of about 2600 $\mathrm{mm}$ per year (Class A pan evaporation) and low precipitation of $470 \mathrm{~mm}$ per year (63-year average). Evaporative demand and precipitation during the growing season (May to September) are $1550 \mathrm{~mm}$ and $320 \mathrm{~mm}$, respectively. Strong advection of heat energy from the South and Southwest is typical, especially during March through June when average 24-hr wind runs at a $2-\mathrm{m}$ height exceed $460 \mathrm{~km}$. The soil was a Pullman clay loam (fine, mixed, thermic torrertic Paleustolls) with slow permeability, having a dense B2 layer from about 0.15- to $0.40-\mathrm{m}$ depth and a calcic horizon that begins at about 1.2- to 1.5-m depth (Taylor et al., 1963; Unger and Pringle, 1981). The four lysimeters are arranged in a square pattern in a 20 ha field, where each lysimeter is located in the center of a 5 ha quadrant, designated NE, SE, NW, and SW. The east quadrants are irrigated with a hose-fed Lindsay* (Lindsay Manufacturing, Omaha, Neb.) lateral move sprinkler, and the west quadrants are dryland and not irrigated (except for a preplant and post emergence irrigation in some years when preseason precipitation was inadequate for germination). The lysimeters have a $9 \mathrm{~m}^{-2}$ area and $2.3 \mathrm{~m}$ deep monolithic cores. Change in lysimeter mass was converted to ET on a depth basis with a precision of $0.05 \mathrm{~mm}$ and reported every $0.5 \mathrm{hr}$ (Marek et al., 1988; Howell et al., 1995). ET depth (mm per $0.5 \mathrm{hr}$ ) was then multiplied by the latent heat of vaporization (with a unit conversion factor of 1361.11) to obtain half-hourly averages of latent heat flux $\left(\mathrm{W} \mathrm{m}^{-2}\right)$. For full cover crops, ET values were multiplied by 0.9868 to account for the crop canopy extending over the $9.5 \mathrm{~mm}$ thick lysimeter walls and midway across the $10 \mathrm{~mm}$ air gap, which increased the total area contributing to ET to $9.18 \mathrm{~m}^{-2}$.

\subsection{Crop surfaces}

Crop surfaces in this study included irrigated alfalfa and dryland grain sorghum in 1997, 1998, and 1999, irrigated cotton in 2000 and 2001, and dryland cotton in 2000. All crops on the lysimeters and surrounding fields were managed similarly. Alfalfa (Pioneer 5454) was seeded on 13 and 14 September 1995 at a rate of $28 \mathrm{~kg} \mathrm{ha}^{-1}$ at $0.20 \mathrm{~m}$ spacing, and maintained in a well-watered condition except for several days before each harvest (10\% to $50 \%$ bloom). Additional details of the alfalfa crop are given in Evett et al. (2000).

Short season grain sorghum (Pioneer 8699) was seeded on 4 June 1997, 24 June 1998, and 28-29 June 1999 in east-west oriented rows without raised beds, and harvested on 14 October 1997, 8 October 1998, and 18 October 1999. Seed spacings were $0.76 \mathrm{~m}$ and $0.25 \mathrm{~m}$ on the NW and SW quadrants respectively, in 1997, and $0.25 \mathrm{~m}$ and $0.76 \mathrm{~m}$ on the NW and SW quadrants respectively, in 1998 and 1999. Plants were thinned to 13 plants $\mathrm{m}^{-2}$ on the lysimeters 3-4 days following emergence each year. The grain sorghum crops were irrigated once before and once after planting (25 mm each) in 1997 and 1998 but no irrigation was applied in 1999.

Irrigated and dryland cotton (Paymaster 2145) was seeded on 16-17 May 2000 and 16-17 May 2001. (The 2001 dryland cotton data was not used in this study because much of the infrared surface temperature data was missing). Irrigated cotton was seeded at 21 and 20 plants $\mathrm{m}^{-2}$ in 2000 and 2001, respectively, on east-west raised beds spaced $0.76 \mathrm{~m}$ with furrow dikes to store irrigation and rainfall. Dryland cotton was seeded at 17 plants $\mathrm{m}^{-2}$ on eastwest rows without beds or dikes at $0.76 \mathrm{~m}$ and $0.25 \mathrm{~m}$ spacing in the NW and SW quadrants, respectively. The irrigated cotton in the NE and SW quadrants was irrigated at 50\% and 100\%, respectively, of the full crop water use in both years. Irrigated cotton was harvested 14 November 2000 and 30 October 2001, and dryland cotton was harvested on 18 October 2000. Additional details of the cotton crops, lysimeters, and irrigation equipment are given in Howell et al. (2002).

* The mention of trade or manufacturer names is made for information only and does not imply an endorsement, recommendation, or exclusion by USDA-Agricultural Research Service. 


\subsection{Plant and micrometeorological measurements}

Plant measurements and samples were taken periodically at key growth stages at 1.0 to $1.5 \mathrm{~m}^{2}$ sites around each lysimeter. Leaf area was measured with a LI-COR leaf area meter (model LI-3100, Lincoln, Neb.), and the meter accuracy was verified periodically with a $0.005 \mathrm{~m}^{2}$ standard disk. Plant height and LAI were linearly interpolated between sample dates to estimate these parameters for each day of the growing season.

Micrometeorological parameters and radiometric surface temperatures were recorded from instrumented masts adjacent to each lysimeter every $6 \mathrm{~s}$ and reported as $0.5 \mathrm{hr}$ averages. Net radiation was measured with a REBS Q*5.5 net radiometer (REBS, Seattle, Wash.), soil heat flux was measured with four REBS HFT-1 heat flux plates buried at 5 $\mathrm{cm}$ with parallel-wired averaging thermocouples at 2 and $4 \mathrm{~cm}$ over each plate. Air temperature and relative humidity (Rotronics MP 100, Huntington, N.Y.) and wind speed (Met One 014A, Grants Pass, Ore.) were measured at $2 \mathrm{~m}$ height over the ground surface. Rainfall was recorded with a Qualimetrics 611-B tipping bucket raingage with the orifice $1 \mathrm{~m}$ above the ground surface. Radiometric surface temperature was measured with an Exergen IRT/C.2-T-80 (Exergen, Newton, Mass.) infrared thermometer (IRT) pointed at the lysimeter surface at $30^{\circ}$ from nadir and facing southward. The IRTs were insulated from the outside air to stabilize their body temperatures by inserting each one into a brass reducer bushing (9.5 mm ID x $12.7 \mathrm{~mm}$ OD), which was secured inside two concentric white PVC reducers (12.7 mm ID x $25.4 \mathrm{~mm}$ OD and $25.4 \mathrm{~mm}$ ID x $41.3 \mathrm{~mm}$ OD). A white PVC cap (25.4 mm ID x $41.3 \mathrm{~mm}$ OD) sealed the end opposite the IRT opening. The IRTs were checked at the beginning of each season with an Omega Black Point BB701 black body calibrator (Omega, Stamford, Conn.) from 5 to $40^{\circ} \mathrm{C}$ in $5^{\circ} \mathrm{C}$ increments in a room at ambient temperature $\left(20^{\circ} \mathrm{C}\right)$.

\subsection{Data screening}

Data were initially screened for days where measured changes in lysimeter mass could potentially compromise the integrity of latent heat flux calculations. This included rainfall events, irrigation, soil water measurements (each lysimeter contains two neutron access tubes), instrument maintenance, or harvest (alfalfa only). The energy balance surface temperature equations assume short-term steady state flux in the soil-plant-atmosphere continuum, which can be disrupted by intermittent clouds, so data were further restricted to days where incoming solar radiation (measured at a nearby weather station east of the field with an Epply PSP pyranometer; Epply Laboratories, Newport, R.I.) and theoretical clear sky radiation (Allen et al., 1998) had a coefficient of determination of at least 0.95 between 0700 to 1900 hours CST. To ensure enough vegetation covered the soil so that radiometric temperature measurements were mainly influenced by canopy temperature, only days where LAI $\geq 0.5$ for alfalfa and LAI $\geq 1.0$ for cotton and sorghum were included. For energy balance calculations, half hourly averages between 1030 and 1530 CST (reported as the midpoint of the time-averaged period and do not reflect daylight savings time; i.e., 1045 to 1515) were used, when net radiation is at least $80 \%$ of its daily peak value. These times include data recorded approximately $\pm 2.5 \mathrm{hr}$ from solar noon, which occurs 1243 to 1254 during the growing season. Finally, the data set was reduced further by considering only days between 15 May and 15 September, which is when atmospheric demand and therefore energy flux at the surface are greatest.

\section{RESULTS AND DISCUSSION}

Table 1 shows regression results for the aerodynamic- and radiometric-air temperature gradient (i.e., $T_{0}-T_{a}$ vs. $T_{s}-T_{a}$, respectively, denoted as $T-T_{a}$ in Table 1), sensible heat flux $(H)$ and latent heat flux (LE). Temperature and energy flux terms are half hour averages between 1030 and 1530 CST. Modeled latent heat flux (LE) was computed using equations (2) to (13), and sensible heat flux $(\mathrm{H})$ was computed using radiometric temperature $\left(\mathrm{T}_{\mathrm{s}}\right)$ in place of aerodynamic surface temperature $\left(T_{0}\right)$ in equation (3), where the scalar roughness length for sensible heat transfer (zoh) was assumed to be a constant one-tenth of the momentum roughness length (i.e, $\mathrm{z}_{\mathrm{oh}}=0 .{ }^{*} \mathrm{z}_{\mathrm{om}}$, or a $=0.1$ in equation 8). Measured $\mathrm{H}$ was taken as the residual of equation (2), and To - Ta was obtained by inverting equation (3) using measured H. It is clear from Table 1 that $\left(T_{o}-T_{a}\right)$ and $\left(T_{s}-T_{a}\right)$ are poorly correlated, even though $T_{o}$ and $T_{s}$ by themselves might show reasonable correlation (data not shown), at least for the present definition of To where $\mathrm{z}_{\mathrm{oh}}=$ $0.1^{*} \mathrm{z}_{\mathrm{om}}$. We did not find any suitable relation for any combination of surface temperatures or surface-air temperature gradients as reported by others. In addition, the regression results for $\mathrm{H}$ and LE, especially the slopes, are different for each type of surface, and the standard error estimate (SE) of the regressions are somewhat greater than those typically 
reported in the literature (e.g., 50 to $100 \mathrm{~W} \mathrm{~m}^{-2}$ ). This may be the result of assuming the same proportionality of roughness lengths for each crop. The radiometer, however, probably views a different top portion of each crop depending on canopy structure (for a fixed view angle), and this portion is also likely to be at a different height than the supposed source-sink for $\mathrm{H}$ where $\mathrm{T}_{\mathrm{o}}$ would occur. The vertical temperature gradient would then cause disagreement between $T_{s}$ and $T_{o}$ (Choudhury et al., 1986; Kalma and Jupp, 1990). Consequently, it may be more physically meaningful to define a radiometric roughness length $\left(\mathrm{z}_{\mathrm{or}}\right)$ for $\mathrm{T}_{\mathrm{s}}$ instead of attempting to adjust $\mathrm{T}_{\mathrm{s}}$.

Table 1. Regressions results between measured parameters and those from the energy balance, where $\mathrm{z}_{\mathrm{oh}} / \mathrm{z}_{\mathrm{om}}=0.1$ for all surfaces.

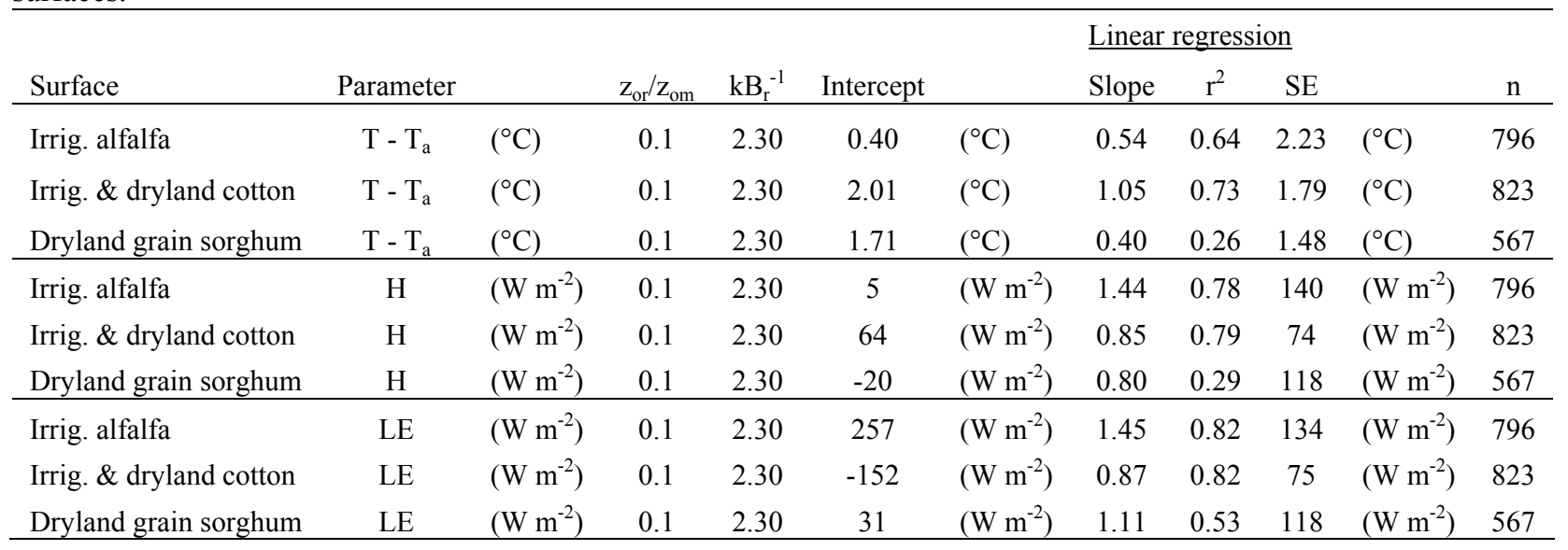

Table 2. Regressions results between measured parameters and those from the energy balance, where $\mathrm{z}_{\mathrm{oh}} / \mathrm{z}_{\mathrm{om}}$ was unique for each surface.

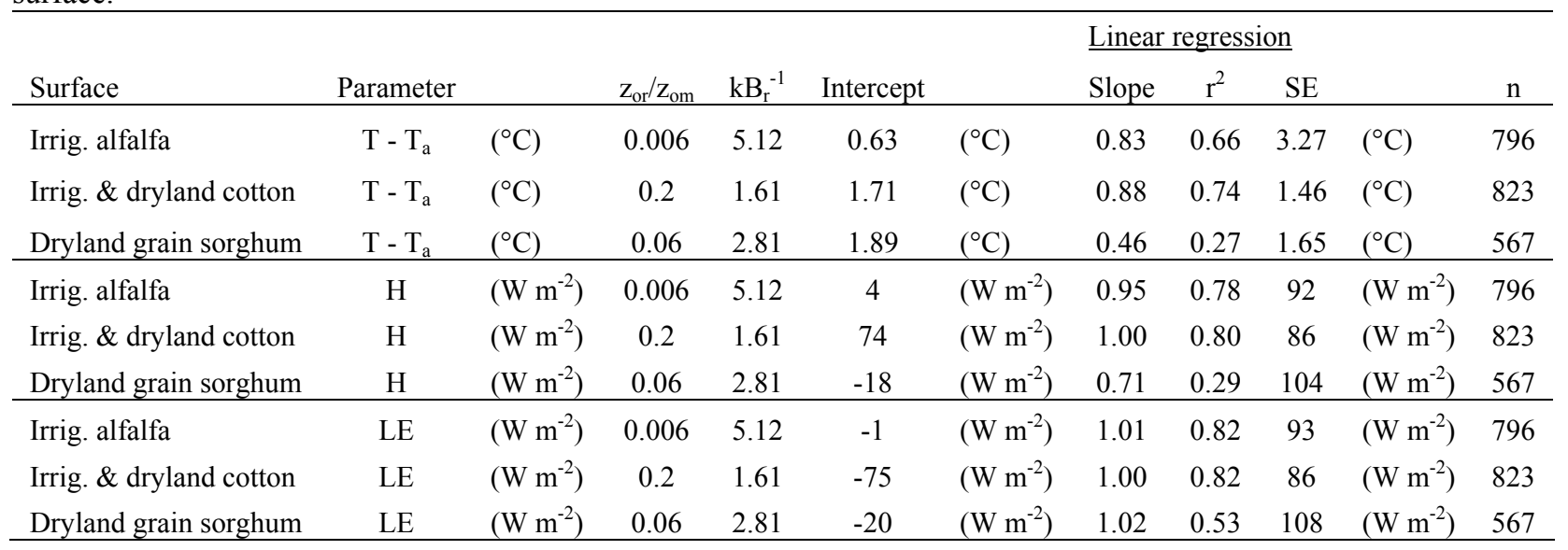

Radiometric roughness lengths $\left(\mathrm{z}_{\mathrm{or}}\right)$ were then estimated for each crop surface. Measured $\mathrm{H}$ and $\mathrm{T}_{\mathrm{s}}$ were substituted into equation (3), and equations (3)-(4) were inverted to solve for $z_{o h}$, which is termed $z_{\text {or }}$ since $T_{s}$ was used in place of $T_{0}$. The average $\mathrm{z}_{\mathrm{or}} / \mathrm{z}_{\mathrm{om}}$ for each crop surface was then used in the energy balance equations as before, and the results are shown in Table 2. This improved the regression results somewhat for $\mathrm{H}$ and LE, but not much for $\mathrm{T}_{0}-\mathrm{T}_{\mathrm{a}}$ vs. $T_{s^{-}} T_{a}$. The resulting average $z_{o r} / z_{o m}$ (or alternatively, $\mathrm{kB}_{\mathrm{r}}^{-1}=\ln \left[\mathrm{z}_{\mathrm{om}} / \mathrm{z}_{\mathrm{or}}\right]$ ) varies by an order of magnitude for each crop surface (i.e., 0.006 for alfalfa, 0.06 for grain sorghum, and 0.2 for cotton). This suggests the magnitude of $\mathrm{z}_{\mathrm{or}} / \mathrm{z}_{\mathrm{om}}$ is directly related to canopy roughness (and perhaps inversely related to LAI, which would agree with the results of Qualls and Brutsaert, 1996; Lhomme et al., 2000; and Suleiman and Crago, 2004). Alfalfa, for example, has a smoother, denser surface (greater plant density), and probably greater LAI (except for several days following a harvest) relative to cotton or grain sorghum. This would attenuate wind velocity and turbulence below the top of the canopy to a greater extent than row crops (i.e., cotton or sorghum). The zero plane displacement (d), and hence the source-sink for sensible heat $\left(d+z_{\mathrm{oh}}\right)$, would be closer to the top of the canopy. If the radiometer viewed mostly the top portion of the canopy in this case, smaller values of $\mathrm{z}_{\mathrm{or}} / \mathrm{z}_{\mathrm{om}}$ would result. Inspection of equation (6) shows that the zero plane 
displacement (d) is directly related to LAI for a given canopy height $\left(h_{c}\right)$, so that for a larger LAI, $d$ is at a greater height in the canopy. But even when alfalfa LAI is temporarily small, its greater plant density may be a compensating factor, and, curiously, we did not observe a relationship between LAI and any form of $\mathrm{z}_{\mathrm{or}}$ (e.g., $\mathrm{z}_{\mathrm{or}} / \mathrm{z}_{\mathrm{om}}, \ln \left[\mathrm{z}_{\mathrm{or}}\right]$, or $\mathrm{kB}_{\mathrm{r}}^{-1}$ ). Cotton, on the other hand, has a coarser plant density (and usually smaller LAI) relative to alfalfa, so $d / h_{c}$ is smaller (d is deeper in the canopy) according to equation (6). Although this may allow the radiometer to view a greater portion of the canopy below the top, the resulting $\mathrm{z}_{\mathrm{or}} / \mathrm{z}_{\mathrm{om}}(=0.2)$ was still much greater than alfalfa, implying the position of $\mathrm{d}$ was deeper in the canopy.

The next step involved exploring what relationships may exist between various forms of the radiometric roughness length and micrometeorological parameters, since our data did not indicate a relationship with LAI. This is desirable because the specific type of vegetation and its roughness characteristics are often unknown when using spatially distributed data from airborne or satellite platforms. We found only weak relationships between $\mathrm{kB}_{\mathrm{r}}^{-1}$ and the product of wind speed (u) or friction velocity $\left(\mathrm{u}_{*}\right)$ and $\mathrm{T}_{\mathrm{s}}-\mathrm{T}_{\mathrm{a}}$ (e.g., Kustas et al.,1989; 1994; Zhang et al., 1995); however, it should be noted that these studies used spatial rather than temporal surface temperature data, which may have had a normalizing effect on temporal micrometeorological variables. A rather strong lognormal relationship was observed between $\mathrm{kB}_{\mathrm{r}}^{-1} \mathrm{e}^{(\mathrm{a} / \mathrm{LAI})}$ (where $\mathrm{a}=-3$ ) and the crop water stress index (CWSI, Jackson et al., 1981; Jackson, 1982) for all three crops (Figure 1). The CWSI baseline temperature was computed based on the wet bulb method outlined by Alves and Pereira (2000), and the upper temperature limit was obtained by setting $H=R_{n}-G$ and inverting equation (3). This relation is not surprising because as CWSI $\rightarrow 0, \mathrm{H}$ and $\mathrm{z}_{\mathrm{or}} \rightarrow 0$, and by definition $\mathrm{kB}_{\mathrm{r}}^{-1} \rightarrow \infty$. Since $\mathrm{z}_{\mathrm{or}}$ also appears in the expression for CWSI and stability correction was necessary, iteration was required to obtain $\mathrm{z}_{\mathrm{or}}$. This approach, however, did not improve estimates of $\mathrm{H}$ or LE over those in Tables 1 or 2 because $\mathrm{z}_{\text {or }}$ did not always converge to reasonable values. This relation did suggest that $\mathrm{z}_{\mathrm{or}}$ may be coupled to both atmospheric demand and crop water status in a manner analogous to bulk canopy resistance (Todorovic, 1999; Lecina et al., 2003).
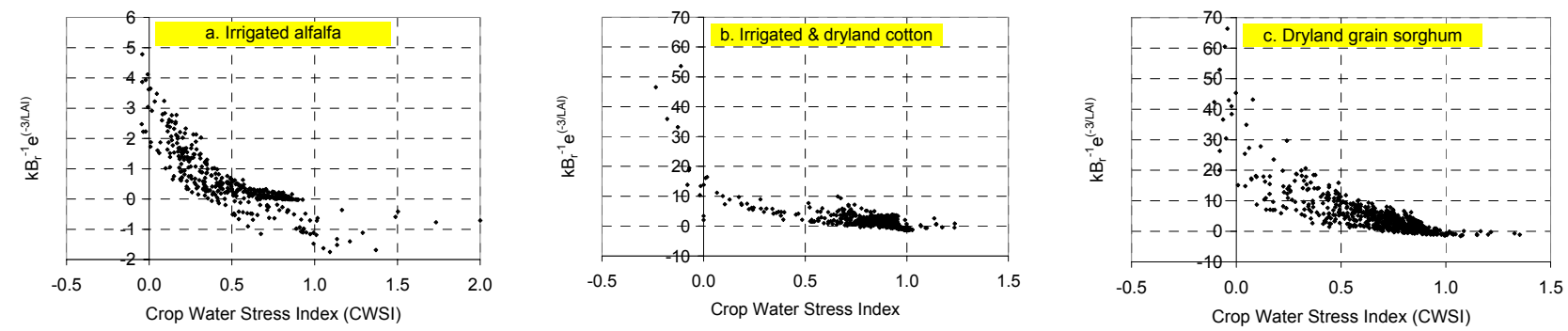

Figure 1. Relationship between $\mathrm{kB}_{\mathrm{r}}^{-1} \mathrm{e}^{(-3 / \mathrm{LAI})}$ and CWSI for each crop surface: (a) irrigated alfalfa; (b) irrigated and dryland cotton; and (c) dryland grain sorghum.

In light of this observation, examination of the daytime energy balance and $\mathrm{kB}_{\mathrm{r}}^{-1}$ on a half hourly basis may provide further insight to the behavior of the radiometric roughness length. Figures $2 a, b$, and $c$ show the daytime energy balance for alfalfa in the SE lysimeter in 1999 for day of year (DOY) 108, 140, and 210, respectively (positive is toward the canopy). These three days were selected to illustrate different $\mathrm{H}$ and LE partitioning. On DOY 108 (figure $4), \mathrm{LAI}=1.9$, and the first cutting of the year had not yet occurred. A larger portion of the available energy $\left(\mathrm{R}_{\mathrm{n}}-\mathrm{G}\right)$ was partitioned to $\mathrm{H}$ than to LE (Bowen ratio $\beta>1$ ) until about 1445, and conditions were non-advective except for a short time in the evening. On DOY 140 (figure 5), LAI $=2.3$, and most available energy was partitioned to LE $(|\beta| \ll 1)$, which included advection after about 1415. On DOY 210 (figure 6), LAI $=3.5$, and conditions were highly advective during most of the day $(0>\beta>-1$, and measured daily ET totaled $12.7 \mathrm{~mm})$.

Figure $2 \mathrm{~d}$ shows the resulting radiometric roughness lengths (expressed as $\mathrm{kB}_{\mathrm{r}}^{-1}=\ln \left[\mathrm{z}_{\mathrm{om}} / \mathrm{z}_{\mathrm{or}}\right]$ for graph clarity) for these three days between 1030 and 1530, when most of the daily energy flux occurs (times are shown as midpoint of each half hour average). The $\mathrm{kB}^{-1}$ values for $\mathrm{z}_{\mathrm{oh}} / \mathrm{z}_{\mathrm{om}}=0.1$ and 0.2 are also shown. The greatest variability of $\mathrm{kB}_{\mathrm{r}}{ }^{-1}$ occurred on DOY 140 , when $\mathrm{H}$ was smallest $\left( \pm 60 \mathrm{~W} \mathrm{~m}^{-2}\right)$, and the least variability on DOY 108 , when $\mathrm{H}$ followed a trend similar to $\mathrm{R}_{\mathrm{n}}$, and $\mathrm{kB}_{\mathrm{r}}^{-1}$ remained fairly constant around $8.0\left(\mathrm{z}_{\mathrm{or}} / \mathrm{z}_{\mathrm{om}}=0.00033\right)$. On DOY 210 , when $\mathrm{H}$ increased during the day, $\mathrm{kB}_{\mathrm{r}}^{-1}$ tended to decrease overall (and $\mathrm{z}_{\mathrm{or}} / \mathrm{z}_{\mathrm{om}}$ increased, resulting in a decrease in aerodynamic resistance). In figure $2 c$, note the small decrease in $R_{n}$ around 1245 to 1315 (apparently from light cirrus clouds). This 
coincides with a small decrease in $\mathrm{kB}_{\mathrm{r}}^{-1}$ from around 8.0 at 1215 and 7.5 at 1345 in figure $2 \mathrm{~d}$. It is possible that $\mathrm{kB}_{\mathrm{r}}^{-1}$ would have otherwise remained around 7.5 to 8.0 at 1245 and 1315 , which is very similar to values on DOY 140 , had $\mathrm{R}_{\mathrm{n}}$ followed theoretical clear sky radiation. This suggests that $\mathrm{kB}_{\mathrm{r}}^{-1}$ is sensitive to sudden, if slight, changes in the energy balance. This has also been observed for $T_{s}-T_{a}$ (Pennington and Heatherly, 1989), from which $\mathrm{kB}_{\mathrm{r}}^{-1}$ is derived. Thus it appears that when $\mathrm{H}$ comprises a considerable portion of the energy balance (i.e., $|\beta|>\sim 0.5$ ) under nonadvective conditions, the $\mathrm{kB}_{\mathrm{r}}^{-1}$ parameter does not vary greatly during daytime hours ( $\pm 2 \mathrm{hr}$ from solar noon), which could be a consequence of the "self-preservation" of the evaporative fraction (Brutsaert and Chen, 1996; Suleiman and Crago, 2004, and others). Todorovic (1999) and Lecina et al. (2003) demonstrated similar behavior for bulk canopy resistance of grass maintained at reference conditions. The $\mathrm{kB}_{\mathrm{r}}^{-1}$ parameter tends to vary more under advective conditions, and is even less predictable for smaller values of $\mathrm{H}$ (i.e., $|\beta|<\sim 0.1$ ) or for disruptions in the energy balance (e.g., intermittent clouds). As mentioned before, since small values of $\mathrm{H}$ do not contribute greatly to the residual energy balance (equation 2), the large variability of $\mathrm{kB}_{\mathrm{r}}^{-1}$ when $\mathrm{H}$ is small is probably inconsequential.
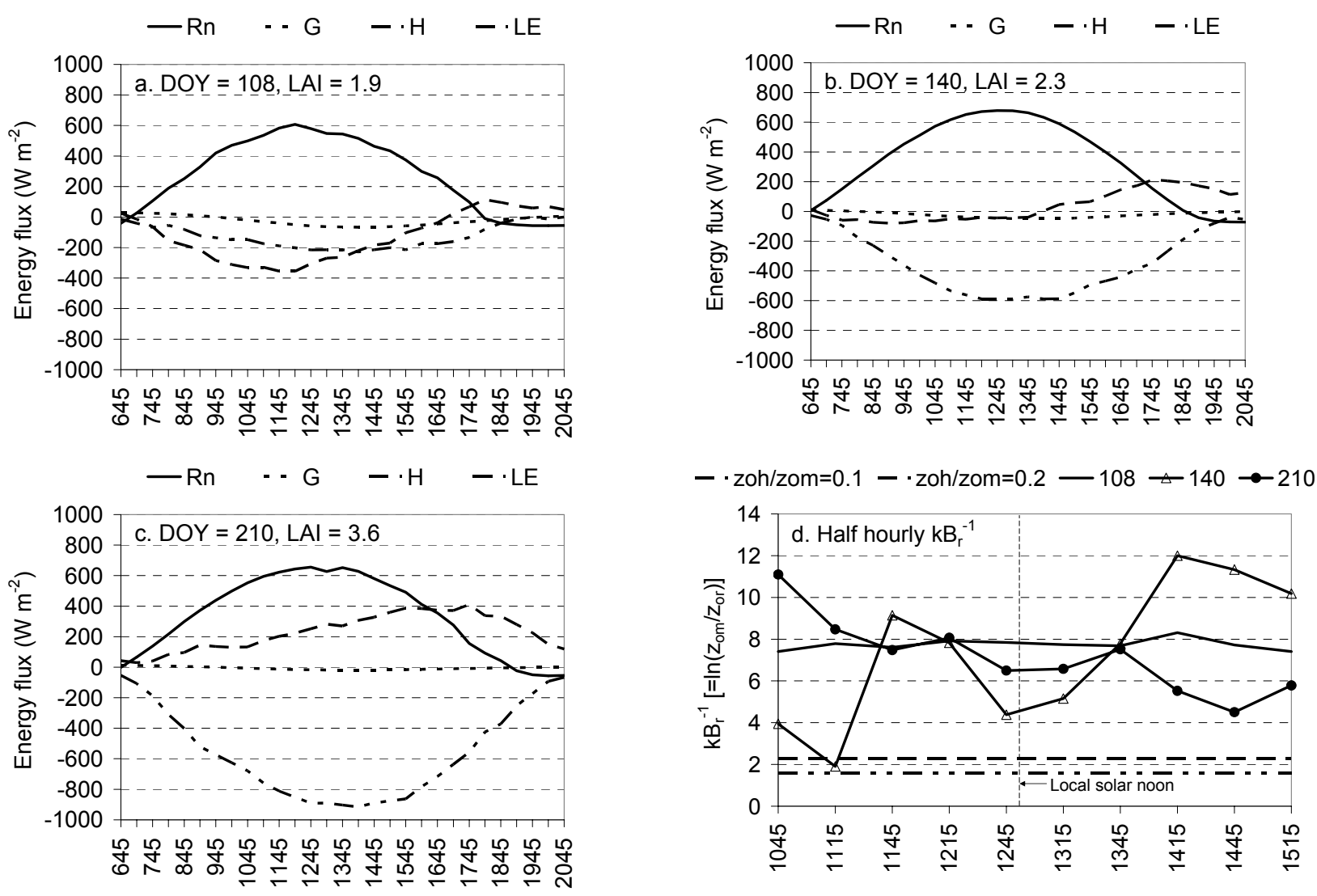

Figure 2. Daytime energy balance for irrigated alfalfa in the SE lysimeter in 1999: (a) DOY 108; (b) DOY 140; (c) DOY 210; and (d) associated $\mathrm{kB}_{\mathrm{r}}^{-1}$ parameters for each day.

So far we have not considered the possible change in apparent emissivity $(\varepsilon)$ of a surface throughout the day, which can cause error in the apparent radiometric temperature. Apparent emissivity $(\varepsilon)$ can be influenced by sun-sensor angle depending on the type of surface, and possibly air temperature if it is enough to influence IRT body temperature (Fuchs and Tanner, 1966; Kimes et al., 1980; Huband and Monteith, 1986a; Wanjura and Upchurch, 1991; Lagouarde et al., 1995; Sugita and Brutsaert, 1996). Figure 3 shows alfalfa LE data (where $\mathrm{z}_{\mathrm{oh}} / \mathrm{z}_{\mathrm{om}}=0.006$ from Table 2) for three half hour averages $(1045,1245$, and 1445; i.e., approximate local solar noon $\pm 2 \mathrm{hr}$ ) and their regression lines. The 1045 and 1445 regressions lines show a considerable intercept (-58 and $+56 \mathrm{~W} \mathrm{~m}^{-2}$, respectively) but a slope near unity, and the 1245 regression line has a slope greater than unity $(1.1)$ and an intercept greater than zero $\left(+40 \mathrm{~W} \mathrm{~m}^{-2}\right)$. Similar trends were observed for cotton and grain sorghum. This suggests that some error in the energy balance - surface temperature model might be due to variation of $\varepsilon$ (and perhaps confounded by $\mathrm{z}_{\mathrm{or}}$ ) for different times of the day. 
To briefly examine this hypothesis (without physical and statistical rigor), $\varepsilon$ was varied by time of day, although it would not be possible to determine the exact cause of this variation (e.g., sun elevation, sun azimuth, IRT body temperature). We did not attempt to measure the apparent emissivity or reflectivity of the surface, but a reasonable estimate for alfalfa might be $\varepsilon=0.97$ (Fuchs and Tanner, 1966). We can then estimate a new timedependent apparent emissivity $\left(\varepsilon^{\prime}\right)$ (neglecting reflectivity of the surrounding canopy) by rearranging the StephanBoltzmann relation as

$$
\varepsilon^{\prime}=0.97 \frac{\mathrm{T}_{\mathrm{S}}^{4}}{\mathrm{~T}_{\mathrm{S}}^{4}}
$$

where $T^{\prime}{ }_{s}$ is obtained by inverting equation 3 in which $H$ was the residual from measured $R_{n}, G$, and LE. Note that $T_{s}$ and $\mathrm{T}_{\mathrm{s}}^{\prime}$ must be converted to Kelvin. Half hour averages of $\varepsilon^{\prime}$ are then tabulated by time and crop surface, and their deviations from $\varepsilon=0.97$ (also assumed for cotton and grain sorghum) are shown in Figure 4. All surfaces began with similar values at 1045, and $\varepsilon^{\prime}$ increased for all surfaces from morning to afternoon. Alfalfa $\varepsilon^{\prime}$ had the greatest increase, and cotton the least. It appears that cotton, with its rougher surface, behaves more like a Lambertian surface (i.e., $\varepsilon^{\prime}$ is less dependent on direction of illumination) than alfalfa because of a greater number of multiple reflections in the canopy (Sutherland and Bartholic, 1977). However, this would not explain the continued increase in $\varepsilon^{\prime}$ following solar noon. It is possible that continued increases in air temperature may have elevated IRT body temperature (despite being well-insulated), which could cause increased long wave radiation within the sensor, resulting in an overestimate of measured $T_{\mathrm{s}}$ and from equation (14) an overestimate of $\varepsilon^{\prime}$. It is also possible that as stable temperature gradients developed in the afternoon due to advection, the position of $\mathrm{T}^{\prime}{ }_{\mathrm{s}}$ fell below the effective sensor view (measured $\mathrm{T}_{\mathrm{s}}$ ), resulting in $T_{s}>T_{s}^{\prime}$. Or, if the position of $T^{\prime}{ }_{s}$ was above $T_{s}$, the result could still be that $T_{s}>T^{\prime}{ }_{s}$ if a small lapse (unstable) gradient was present inside the canopy (Kalma and Jupp, 1990).

The use of $\varepsilon$ that varies by time of day (from Figure 4) did not result in uniform improvement of the regression parameters over those of Table 2 (data not shown). This could be the result of using the same $\mathrm{z}_{\mathrm{or}} / \mathrm{z}_{\mathrm{om}}$ parameters that were used for each surface without varying $\varepsilon$. Thus it may be possible to further reduce model error by optimizing the radiometric roughness length by time of day. To explore this (again, without physical or statistical rigor), the Excel Solver function was used to adjust the $\mathrm{z}_{\mathrm{or}} / \mathrm{z}_{\text {om }}$ parameter for each half hour average of $\varepsilon^{\prime}$, with the target being to set the regression slope equal to one. Figure 5 shows the resulting $\mathrm{kB}_{\mathrm{r}}^{-1}$ values (to two significant figures), and Table 3 shows the regression results. The $\mathrm{kB}_{\mathrm{r}}^{-1}$ values did not vary greatly over time for each surface; however, the standard errors of regression were reduced slightly for $\mathrm{H}$ and LE in most cases compared to Tables 1 and 2. Thus varying the $\mathrm{kB}_{\mathrm{r}}^{-1}$ parameter over time may improve the energy balance model.

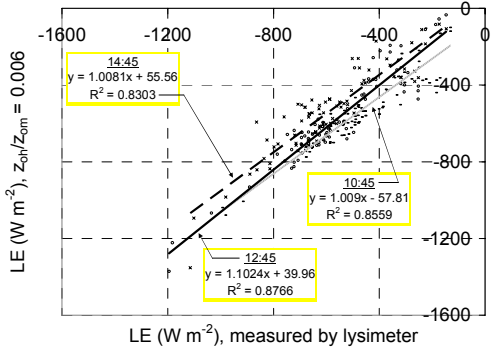

Figure 3. Irrigated alfalfa measured and modeled LE for three half hourly averages.

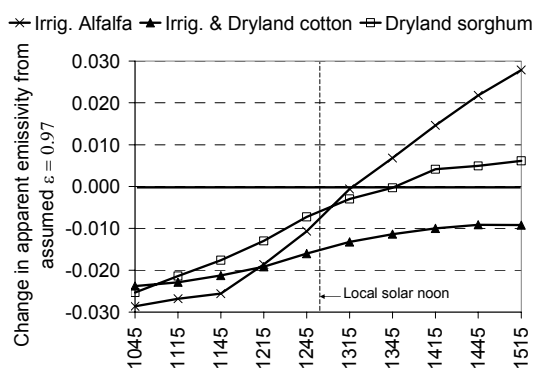

Figure 4. Half hour averages of $\varepsilon^{\prime}$ (from eq. 14) for each crop surface.

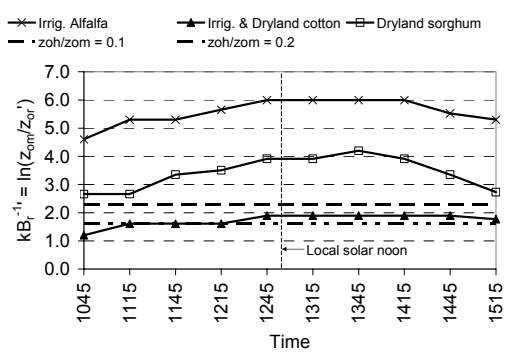

Figure 5. Half hour averages of $\mathrm{kB}_{\mathrm{r}}^{-1}$ associated with $\varepsilon^{\prime}$ (from Fig. 4) for each crop surface. 
Table 3. Regressions results between measured parameters and those from the energy balance, where $\varepsilon^{\prime}$ (from Fig. 4) and $\mathrm{z}_{\mathrm{oh}} / \mathrm{z}_{\mathrm{om}}$ (from Fig. 5) and were varied by time of day for each surface.

\begin{tabular}{|c|c|c|c|c|c|c|c|c|c|c|}
\hline \multirow[b]{2}{*}{ Surface } & \multirow[b]{2}{*}{ Parameter } & & \multirow[b]{2}{*}{$\mathrm{kB}_{\mathrm{r}}^{-1}$} & \multirow[b]{2}{*}{ Intercept } & & \multicolumn{3}{|c|}{ Linear regression } & & \multirow[b]{2}{*}{$\mathrm{n}$} \\
\hline & & & & & & Slope & $r^{2}$ & SE & & \\
\hline Irrig. alfalfa & $\mathrm{T}-\mathrm{T}_{\mathrm{a}}$ & $\left({ }^{\circ} \mathrm{C}\right)$ & Varies by time of day & 0.59 & $\left({ }^{\circ} \mathrm{C}\right)$ & 0.88 & 0.67 & 3.37 & $\left({ }^{\circ} \mathrm{C}\right)$ & 796 \\
\hline Irrig. \& dryland cotton & $\mathrm{T}-\mathrm{T}_{\mathrm{a}}$ & $\left({ }^{\circ} \mathrm{C}\right)$ & Varies by time of day & 1.63 & $\left({ }^{\circ} \mathrm{C}\right)$ & 0.92 & 0.77 & 1.41 & $\left({ }^{\circ} \mathrm{C}\right)$ & 823 \\
\hline Dryland grain sorghum & $\mathrm{T}-\mathrm{T}_{\mathrm{a}}$ & $\left({ }^{\circ} \mathrm{C}\right)$ & Varies by time of day & 2.00 & $\left({ }^{\circ} \mathrm{C}\right)$ & 0.55 & 0.32 & 1.77 & $\left({ }^{\circ} \mathrm{C}\right)$ & 567 \\
\hline Irrig. alfalfa & $\mathrm{H}$ & $\left(\mathrm{W} \mathrm{m}^{-2}\right)$ & Varies by time of day & -1 & $\left(\mathrm{~W} \mathrm{~m}^{-2}\right)$ & 0.98 & 0.83 & 81 & $\left(\mathrm{~W} \mathrm{~m}^{-2}\right)$ & 796 \\
\hline Irrig. \& dryland cotton & $\mathrm{H}$ & $\left(\mathrm{W} \mathrm{m}^{-2}\right)$ & Varies by time of day & -9 & $\left(\mathrm{~W} \mathrm{~m}^{-2}\right)$ & 0.97 & 0.78 & 88 & $\left(\mathrm{~W} \mathrm{~m}^{-2}\right)$ & 823 \\
\hline Dryland grain sorghum & $\mathrm{H}$ & $\left(\mathrm{W} \mathrm{m}^{-2}\right)$ & Varies by time of day & -28 & $\left(\mathrm{~W} \mathrm{~m}^{-2}\right)$ & 0.79 & 0.41 & 89 & $\left(\mathrm{~W} \mathrm{~m}^{-2}\right)$ & 567 \\
\hline Irrig. alfalfa & LE & $\left(\mathrm{W} \mathrm{m}^{-2}\right)$ & Varies by time of day & -1 & $\left(\mathrm{~W} \mathrm{~m}^{-2}\right)$ & 1.00 & 0.86 & 81 & $\left(\mathrm{~W} \mathrm{~m}^{-2}\right)$ & 796 \\
\hline Irrig. \& dryland cotton & LE & $\left(\mathrm{W} \mathrm{m}^{-2}\right)$ & Varies by time of day & -16 & $\left(\mathrm{~W} \mathrm{~m}^{-2}\right)$ & 0.96 & 0.80 & 87 & $\left(\mathrm{~W} \mathrm{~m}^{-2}\right)$ & 823 \\
\hline Dryland grain sorghum & LE & $\left(\mathrm{W} \mathrm{m}^{-2}\right)$ & Varies by time of day & -8 & $\left(\mathrm{~W} \mathrm{~m}^{-2}\right)$ & 0.99 & 0.60 & 91 & $\left(\mathrm{~W} \mathrm{~m}^{-2}\right)$ & 567 \\
\hline
\end{tabular}

\section{SUMMARY AND CONCLUSIONS}

The single source energy balance for the soil-plant-atmosphere continuum, which commonly uses radiometric temperature $\left(T_{s}\right)$ as a surrogate for aerodynamic temperature $\left(T_{0}\right)$ at the surface, was evaluated for several years of full cover irrigated alfalfa, irrigated and dryland cotton, and dryland grain sorghum. The model was tested against half hourly evapotranspiration (ET) data measured by large, precision weighing lysimeters in Bushland, Texas. $\mathrm{T}_{\mathrm{s}}$ was measured and averaged each half hour by ground-based infrared thermometers mounted over the lysimeters. This is in the Southern High Plains, which is notable for its strong regional advection and wide range of climatic variability.

The energy balance was first tested using a constant scalar - momentum roughness length ratio $\left(\mathrm{z}_{\mathrm{oh}} / \mathrm{z}_{\mathrm{om}}=0.1\right.$, which is generally accepted for full cover crops). Regression results for sensible and latent heat flux (H and LE, respectively) were different for each crop, especially the slopes. No relationship was observed between the $T_{\mathrm{s}}$ and $\mathrm{T}_{\mathrm{o}}-$ air vertical temperature gradients for any crop.

Next, the energy balance was inverted to obtain the scalar roughness length, which was termed the radiometric roughness length $\left(\mathrm{z}_{\mathrm{or}}\right)$ because $\mathrm{T}_{\mathrm{s}}$ was used in place of $\mathrm{T}_{\mathrm{o}}$ in the sensible heat flux equation. The average $\mathrm{z}_{\mathrm{or}}$ for each crop surface was used in the energy balance, which improved the regression results for $\mathrm{H}$ and LE but not for the vertical temperature gradients $\left(T_{s}-T_{a}\right.$ and $\left.T_{o}-T_{a}\right)$. This implied that $z_{o h} / z_{o m}$ depended largely on the surface roughness.

Several empirical parameterizations for $\mathrm{z}_{\mathrm{or}}$ (often in the $\mathrm{kB}_{\mathrm{r}}^{-1}=\ln \left[\mathrm{z}_{\mathrm{om}} / \mathrm{z}_{\mathrm{or}}\right]$ form) from previous studies were tested, but only weak relationships were found. A rather strong lognormal relation between $\mathrm{kB}_{\mathrm{r}}^{-1} \mathrm{e}^{(\mathrm{a} / \mathrm{LAI})}$ (where LAI = leaf area index and $\mathrm{a}=-3$ ) and the crop water stress index (CWSI) was observed, but $\mathrm{z}_{\mathrm{or}}$ (solved for by iteration because $\mathrm{z}_{\text {or }}$ also appears in the CWSI) often did not converge to reasonable values. For moderate to large Bowen ratios $(\beta)$ without advection, the $\mathrm{kB}_{\mathrm{r}}^{-1}$ parameter tended not to vary much for a given day, analogous to the concept of self preservation of the evaporative fraction. Variation was greatest for smaller values of $|\beta|$ (which may be inconsequential because most available energy is partitioned to LE in this case), and moderate for advective conditions.

The effect of varying apparent emissivity $(\varepsilon)$ by time of day was examined. Error in the energy balance was not reduced unless $\mathrm{z}_{\mathrm{or}} / \mathrm{z}_{\mathrm{om}}$ was also allowed to vary slightly by time of day, which then resulted in generally the smallest standard errors (SE) of the regression for $\mathrm{H}$ and LE. Values of $\varepsilon$ and $\mathrm{z}_{\mathrm{or}} / \mathrm{z}_{\mathrm{om}}$ (in $\mathrm{kB}_{\mathrm{r}}^{-1}$ form) shown in this paper that vary by time of day were for illustrative purposes only and should not be used without further rigorous validation. 


\section{ACKNOWLEDGEMENTS}

The authors are grateful to the following for their many years of assistance and dedication in the design, maintenance, operation, improvement, and data processing of the precision weighing lysimeters at the USDA-ARS Conservation and Production Research Laboratory in Bushland, Texas: Mr. Keith Brock, Mr. Jim Cresap, Mr. Grant Johnson, Mr. M.D. McRoberts, and Mr. Brice Ruthhardt, biological technicians, Ms. Karen Copeland, soil scientist, Mr. Donald Dusek, agronomist, Dr. Arland D. Schneider, agricultural engineer (ret.), all with the USDA-ARS, and to Mr. Thomas Marek, agricultural engineer, at the Texas Agricultural Experiment Station in Amarillo, Texas.

\section{REFERENCES}

Allen, R. G., Jensen, M. E., Wright, J. L., and Burman, R. D. 1989. Operational Estimates Of Reference Evapotranspiration. Agron. J. 81:650-662.

Allen, R. G., L. S. Periera, D. Raes, and M. Smith. 1998. Crop evapotranspiration: Guidelines for computing crop water requirements. Irrig. and Drain. Paper No. 56. United Nations, Food and Agric. Org.: Rome, Italy.

Alves, I., Fontes, J. C., and Pereira, L. S. 2000a. Evapotranspiration estimation from infrared surface temperature. I: The performance of the flux equation. Trans. ASAE 43(3):591-598.

Alves, I., Fontes, J. C., and Pereira, L. S. 2000b. Evapotranspiration estimation from infrared surface temperature. II: The surface temperature as a wet bulb temperature. Trans. ASAE 43(3):599-602.

Alves, I. and Pereira, L. S. 2000. Non-water-stressed baselines for irrigation scheduling with infrared thermometers: A new approach. Irrig. Sci. 19:101-106.

Brutsaert, W. and Chen, D. 1996. Diurnal variation of surface fluxes during thorough drying (or severe drought) of natural prairie. Water Resources Res. 32(7):2013-2019.

Brutsaert, W. 1982. Evaporation into the atmosphere. R. Deidel, Dordrecht, The Netherlands.

Campbell, G. S. 1977. An introduction to environmental physics. Springer, New York.

Chamberlain, A. C. 1968. Transport of gases to and from surfaces with bluff and wave-like roughness elements. Q.J.R. Meteorol. Soc., 94:318-332.

Chehbouni, A., Lo Seen, D. L., Njoku, E. G., and Monteny, B. M. 1996. Examination of the difference between radiative and aerodynamic surface temperatures over sparsely vegetated surfaces. Remote Sens. Environ. 58:177-186.

Chehbouni, A. Nouvellon, Y., Lhomme, J.-P., Watts, C., Boulet, G., Kerr, Y. H., Moran, M. S., and Goodrich, D. C. 2001. Estimation of surface sensible heat flux using dual angle observations of radiative surface temperature. Agric. For. Meteorol. 108:55-65

Choudhury, B. J., Reginato, R. J., and Idso, S. B. 1986. An analysis of infrared temperature observations over wheat and calculation of latent heat flux. Agric. For. Meteorol. 37-75-88.

Crago, R. D. 1998. Radiometric and equivalent isothermal surface temperatures. Water Resources Res. 34(11):30173023 .

Evett, S.R., T.A. Howell, R.W. Todd, A.D. Schneider, and J.A. Tolk. 2000. Alfalfa reference ET measurement and prediction. In Proc. 4th Decennial National Irrigation Symposium, R. G. Evans, B. L. Benham, and T. P. Trooien, eds., Phoenix, AZ., 14-16 Nov., 266-272. ASAE: St. Joseph, MI.

Fuchs, M. and Tanner, C. B. 1966. Infrared thermometry of vegetation Agron. J. 58:597-601. 
Hatfield, J. L., Reginato, R. J., and Idso, S. B. 1984. Evaluation of canopy temperature-evapotranspiration models over various crops. Agric. For. Meteorol. 32:41-53.

Howell, T.A., S.R. Evett, J.A. Tolk, and A.D. Schneider. 2002. Evapotranspiration of full-, deficit-irrigated and dryland cotton on the northern Texas High Plains. In Proc.2002 USCID/EWRI Conference. Energy, Climate, Environment and Water - Issues and Opportunities for Irrigation and Drainage. C. M. Burt and S. S. Anderson, eds., 321-339. U.S. Committee on Irrigation and Drainage: Denver, CO.

Howell, T. A., Schneider, A. D., Dusek, D. A., Marek, T. H., and Steiner, J. L. 1995. Calibration and scale performance of Bushland weighing lysimeters. Trans. ASAE 38(4):1019-1024.

Huband, N. D. S. and Monteith, J. L. 1986a. Radiative surface temperature and energy balance of a wheat canopy I: Comparison of radiative and aerodynamic canopy temperature. Boundary-Layer Meteorol. 36:1-17.

Huband, N. D. S. and Monteith, J. L. 1986b. Radiative surface temperature and energy balance of a wheat canopy II: Estimating fluxes of sensible and latent heat. Boundary-Layer Meteorol. 36:107-116.

Jackson, R. D. 1982. Canopy temperature and crop water stress. In Advances in Irrigation, D. Hillel, ed., Vol. 1, Academic Press: New York, 43-85.

Jackson, R. D., Idso, S. B., Reginato, R. J., and Pinter, P. J., Jr. 1981. Canopy temperature as a crop water stress indicator. Water Resources Res. 17(4):1133-1138.

Jackson, R. D., Moran, M. S., Gay, L. W., and Raymond, L. H. 1987. Evaluating evaporation from field crops using airborne radiometry and ground-based meteorological data. Irrig. Sci. 8:81-90.

Jackson, R. D., Pinter, P. J. Jr., and Reginato, R. J. 1985. Net radiation calculated from remote multispectral and ground station meteorological data. Agric. For. Meteorol. 35:153-164.

Jensen, M. E., Burman, R. D., and Allen, R. G., eds. 1990. Evapotranspiration and irrigation water requirements. ASCE Manuals and Reports on Engrg. Pract. No. 70, ASCE, Reston, VA.

Kalma, J. D., and Jupp, D. L. B. 1990. Estimating evaporation from pasture using infrared thermometry: evaluation of a one-layer resistance model. Agric. For. Meteorol. 51:223-246.

Kimes, D. S. , Idso, S. B., Pinter, P. J. Jr., Reginato, R. J., and Jackson, R. D. 1980. View angle effects in the radiometric measurement of plant canopy. Remote Sens. Environ. 10:273-284.

Kustas, W. P., Choudhury, B. J., Moran, M. S., Reginato, R. J., Jackson, R. D., Gay, L. W., and Weaver, H. L. 1989. Determination of sensible heat flux over sparse canopy using thermal infrared data. Agric. For. Meteorol. 44:197-216.

Kustas, W. P., Perry, E. M., Doraiswamy, P. C., and Moran, M. S. 1994. Using satellite remote sensing to extrapolate evapotranspiration estimates in time and space over a semiarid rangeland basin. Remote Sens. Environ. 49:275-286.

Lagouarde, P. P., Kerr, Y. H., and Brunet, Y. 1995. An experimental study of angular effects on surface temperature for various plant canopies and bare soils. Agric. For. Meteorol. 77:167-190.

Lecina, S., Martínez-Cob, A., Pérez, P. J., Villalobos, F. J., and Baselga, J. J. 2003. Fixed versus variable bulk canopy resistance for reference evapotranspiration estimation using the Penman-Monteith equation under semiarid conditions. Agric. Water Mgmt. 60:181-198.

Lhomme, J.-P., Monteny, B., and Amadou, M. 1994. Estimating sensible heat flux from radiometric temperature over sparse millet. Agric. For. Meteorol. 68:77-91. 
Lhomme, J. P., Chehbouni, A., and Monteny, B. 2000. Sensible heat flux-radiometric surface temperature relationship over sparse vegetation: Parameterizing B ${ }^{-1}$. Boundary Layer Meteorol. 97:431-457.

Mahrt, L., and Vickers, D. 2004. Bulk formulation of the surface heat flux. Boundary Layer Meteorol. 110:357-379.

Marek, T. H., Schneider, A. D., Howell, T. A., and Ebeling, L. L. 1988. Design and construction of large weighing monolithic lysimeters. Trans. ASAE 31(2):477-484.

Merlin, O., and Chehbouni, A. 2004. Different approaches in estimating heat flux using dual angle observations of radiative surface temperature. Int. J. Remote Sens. 25(1):275-289.

Monin, A. S. and Obukhov, A. M. 1954. Dimensionless characteristics of turbulence in the surface layer. Akad. Nauk. SSSR Geofiz. Inst. Tr. 24:163-187.

Monteith, J. L. 1973. Principles of environmental physics. Edward Arnold, London.

Moran, M. S.; Jackson, R. D.; Raymond, L. H.; Gay, L. W., and Slater, P. N., 1989. Mapping surface energy balance components by combining Landsat Thematic Mapper and ground-based meteorological data. Remote Sens. Environ. 30(1):77-87.

Paulson, C. A. 1970. The mathematical representation of wind speed and temperature profiles in the unstable atmospheric surface layer. J. Appl. Meteorol. 9(857-861).

Pennington, D. A., and Heatherly, L. 1989. Effects of changing solar radiation on canopy-air temperatures of cotton and soybeans. Agric. For. Meteorol. 46:1-14.

Pereira, L. S.; Perrier, A.; Allen, R. G., and Alves, I. 1999. Evapotranspiration: concepts and future trends. J. Irrig. Drain. Engrg. 125(2):45-51.

Perrier, A. 1975. Étude de l'évapotranspiration dans les conditions naturelles. III: Evapotranspiration réelle et potentielle des couverts végetaux. Ann. Agron., Paris, 26:229-245.

Perrier, A. 1982. Land surface processes: Vegetation. In Land surface processes in atmospheric general circulation models, P. S. Eagleson, ed. Cambridge University Press, Cambridge, U.K., 395-448.

Qualls, R. J. and Brutsaert, W., 1996. Effect of vegetation density on the parameterization of scalar roughness to estimate spatially distributed sensible heat fluxes. Water Resources Res. 32(3):645-652.

Reginato, R. J., Jackson, R. D., and Pinter, P. J. Jr. 1985. Evapotranspiration calculated from remote multispectral and ground station meteorological data. Remote Sens. Environ. 18:75-89.

Sugita, M. and Brutsaert, W. 1996. Optimal measurement strategy for surface temperature to determine sensible heat flux from anisothermal vegetation. Water Resources Res. 32(7):2129-2134.

Suleiman, A. and Crago, R. 2004. Hourly and daytime evapotranspiration from grassland using radiometric surface temperatures. Agron. J. 96:384-390.

Sun, J., Massman, W., and Grantz, D. A. 1999. Aerodynamic variables in the bulk formulation of turbulent fluxes. Boundary Layer Meteorol. 91:109-125.

Sutherland, R. A. and Bartholic, J. F. 1977. Significance of vegetation in interpreting thermal radiation from a terrestrial surface. J. Appl. Meteorol. 16:759-763. 
Taylor, H. M., Van Doren, C. E., Godfrey, C. L., and Coover, J. R. 1963. Soils of the Southwestern Great Plains Field Station. MP-669, Texas A\&M Univ., Texas Agric. Exp. Stat., College Station, TX.

Todorovic, M. 1999. Single-layer evapotranspiration model with variable canopy resistance. J. Irrig. Drain. Engrg. 125(5):235-245.

Tolk, J. A., Howell, T. A., Steiner, J. L., and Krieg, D. R. 1995. Aerodynamic characteristics of corn as determined by energy balance techniques. Agron. J. 87(4):464-473.

Unger, P. W. and Pringle, F. B. 1981. Pullman Soils: Distribution, Importance, Variability, and Managemen.t B-1372, Texas A\&M Univ., Texas Agric. Exp. Stat., College Station, TX.

Wanjura, D. F. and Upchurch, D. R. 1991. Infrared thermometer calibration and viewing method effects on canopy temperature measurement. Agric. For. Meteorol. 55:309-321.

Wanjura, D. F. and Upchurch, D. R. 1996. Time thresholds for canopy temperature-based irrigation. In Evapotranspiration and Irrigation Scheduling. Proc Int. Conf., C. R. Camp, E. J. Sadler, and R. E. Yoder, eds. San Antonio, Texas, 3-6 Nov., 295-303. ASAE: St. Joseph, MI.

Webb, E. K. Profile relationships: the log-linear range, and extension to strong stability. Q. J. R. Meteorol. Soc. 96:6790 .

Zhang, L.; Lemeur, R., and Goutorbe, J. P. 1995. A one-layer resistance model for estimating regional evapotranspiration using remote sensing data. Agric. For. Meteorol. 77(3-4):241-261.

Zibognon, M., Crago, R., and Suleiman, A. 2002. Conversion of radiometric to aerodynamic surface temperature with an anisothermal canopy model. Water Resources Res. 38(6):3-1 - 3-6. 